\title{
Addressing Lead Toxicity: Complexation of Lead(II) with Thiopyrone and Hydroxypyridinethione O,S Mixed Chelators
}

\author{
Jana A. Lewis and Seth M. Cohen* \\ Department of Chemistry and Biochemistry, University of California, San Diego, La Jolla, \\ California 92093-0358
}

scohen@ucsd.edu

\section{Supporting Information}

*Author to whom correspondence should be addressed. Telephone: (858) 822-5596. Fax: (858) 822-5598. E-mail: scohen@ucsd.edu. 
General. Unless otherwise noted, starting materials were obtained from commercial suppliers and used without further purification. Thiomaltol was synthesized as previously described (Lewis, J.A.; Puerta, D. T.; Cohen, S. M. Inorg. Chem. 2003, 42, 7455-7459). Elemental analysis was performed at NuMega Resonance Labs, San Diego, California. ${ }^{1} \mathrm{H} /{ }^{13} \mathrm{C}$ NMR spectra were recorded on a Varian FT-NMR spectrometer running at 300 or $400 \mathrm{MHz}$ at the Department of Chemistry and Biochemistry, University of California, San Diego. Infrared spectra were collected on a Mattson Research Series FT-IR instrument (using KBr pellets, laboratory of Prof. Clifford P. Kubiak) or a Perkin Elmer Spectrum One FT-IR Spectrometer (using attenuated total reflectance, ATR), at the Department of Chemistry and Biochemistry, University of California, San Diego.

1-Methyl-3-hydroxy-2(1H)-pyridinethione (3,2-HOPTO). 1-Methyl-3-hydroxy-2(1H)pyridinone (3,2-HOPO, $500 \mathrm{mg}, 3.96 \mathrm{mmol})$ was ground together with $\mathrm{P}_{4} \mathrm{~S}_{10}(881 \mathrm{mg}, 1.98$ mmol) in a mortar and pestle to form a yellow-orange powder. The powder was stirred under nitrogen in a flask fitted with a condenser and heated to $175^{\circ} \mathrm{C}$ for $1.5 \mathrm{~h}$. The reaction flask was covered in aluminum foil during the reaction. The tan glassy solid product was dissolved with gentle heating in $25 \mathrm{~mL}$ of $\mathrm{ddH}_{2} \mathrm{O}$ to yield a clear, tan liquid. A small amount of insoluble dark brown material was removed by hot filtration, and upon cooling the filtrate in an ice bath the product crystallized as tan needles. The product was isolated by vacuum filtration and rinsed with cold water. The remaining filtrate was concentrated on rotary evaporator and was stored at $4{ }^{\circ} \mathrm{C}$ overnight to yield a second crop of product, which was isolated by vacuum filtration. Yield: $35 \%$. Mp $116-117^{\circ} \mathrm{C} .{ }^{1} \mathrm{H}$ NMR $\left(\mathrm{CDCl}_{3}, 300 \mathrm{MHz}, 25^{\circ} \mathrm{C}\right): \delta 4.03\left(\mathrm{~s}, 3 \mathrm{H},-\mathrm{CH}_{3}\right), 6.62$ (t, $J=7.0 \mathrm{~Hz}, 1 \mathrm{H}, \mathrm{Ar}-\mathrm{H}), 6.95(\mathrm{~d}, J=7.8 \mathrm{~Hz}, 1 \mathrm{H}, \mathrm{Ar}-\mathrm{H}), 7.34$ (d, $J=6.6,1 \mathrm{H}, \mathrm{Ar}-\mathrm{H}), 8.46(\mathrm{~s}$, $1 \mathrm{H},-\mathrm{OH}) .{ }^{13} \mathrm{C} \mathrm{NMR}\left(\mathrm{CDCl}_{3}, 100 \mathrm{MHz}, 25{ }^{\circ} \mathrm{C}\right): \delta 47.0\left(-\mathrm{CH}_{3}\right), 112.2(\mathrm{Ar}-\mathrm{C}), 113.7(\mathrm{Ar}-\mathrm{C})$, $132.0(\mathrm{Ar}-\mathrm{C}), 155.2(\mathrm{Ar}-\mathrm{C}), 169.3(\mathrm{C}=\mathrm{S})$. GC-EIMS: $m / z 141.0\left[\mathrm{M}^{\circ}\right]^{+}$. IR (solid pellet with 
$\mathrm{KBr}): \quad v 450,515,632,711,773,1044,1134,1282,1353,1415,1473,1554,1627,3131(\mathrm{OH})$

$\mathrm{cm}^{-1}$. Anal. Calcd. for $\mathrm{C}_{6} \mathrm{H}_{7} \mathrm{NOS}$ : C, 51.04; H, 5.00; N, 9.92. Found: C, 50.82; H, 5.17; N, 9.89.

3-Hydroxy-1,2-dimethyl-4(1H)-pyridinethione (3,4-HOPTO). 3-Hydroxy-1,2-dimethyl4(1H)-pyridinone (3,4-HOPO, $500 \mathrm{mg}, 3.59 \mathrm{mmol})$ was ground together with $\mathrm{P}_{4} \mathrm{~S}_{10}(799 \mathrm{mg}$, $1.80 \mathrm{mmol}$ ) in a mortar and pestle to form a light yellow powder. The powder was stirred under nitrogen in a flask fitted with a condenser and heated to $175^{\circ} \mathrm{C}$ for $1.5 \mathrm{~h}$. The reaction flask was covered in aluminum foil during the reaction. The pale yellow solid product was dissolved with gentle heating in $25 \mathrm{~mL}$ of water to yield a clear, orange solution. A small amount of insoluble dark brown material was removed by hot filtration, and upon cooling the filtrate in an ice bath the product crystallized as tan needles. The product was isolated by vacuum filtration and rinsed with cold water. The remaining filtrate was concentrated on rotary evaporator and was stored at $4{ }^{\circ} \mathrm{C}$ overnight to yield a second crop of product, which was isolated by vacuum filtration. Yield: $50 \%$. Mp $166-168{ }^{\circ} \mathrm{C} .{ }^{1} \mathrm{H}$ NMR $\left(d^{6}-\mathrm{DMSO}, 300 \mathrm{MHz}, 25{ }^{\circ} \mathrm{C}\right): \delta 2.41\left(\mathrm{~s}, 3 \mathrm{H},-\mathrm{CH}_{3}\right)$, $3.81\left(\mathrm{~s}, 3 \mathrm{H},-\mathrm{CH}_{3}\right), 7.25(\mathrm{~d}, J=6.6 \mathrm{~Hz}, 1 \mathrm{H}, \mathrm{Ar}-\mathrm{H}), 7.63(\mathrm{~d}, J=6.6,1 \mathrm{H}, \mathrm{Ar}-\mathrm{H}), 8.71(\mathrm{~s}, 1 \mathrm{H},-$ OH). ${ }^{13} \mathrm{C}$ NMR $\left(d^{6}-\mathrm{DMSO}, 100 \mathrm{MHz}, 25{ }^{\circ} \mathrm{C}\right): \delta 13.4\left(-\mathrm{CH}_{3}\right), 43.5\left(-\mathrm{CH}_{3}\right), 125.0(\mathrm{Ar}-\mathrm{C})$, $129.7(\mathrm{Ar}-\mathrm{C}), 133.8(\mathrm{Ar}-\mathrm{C}), 152.7(\mathrm{Ar}-\mathrm{C}), 168.6(\mathrm{C}=\mathrm{S}) . \quad$ GC-EIMS: $m / z 155.0\left[\mathrm{M}^{*}\right]^{+} . \quad \mathrm{IR}$ (solid pellet with $\mathrm{KBr}$ ): $v 561,675,706,806,887,941,1097,1196,1273,1350,1456,1620$, $3074(\mathrm{OH}) \mathrm{cm}^{-1}$. Anal. Calcd. for $\mathrm{C}_{7} \mathrm{H}_{9} \mathrm{NOS}: \mathrm{C}, 54.17 ; \mathrm{H}, 5.84 ; \mathrm{N}, 9.02$. Found: $\mathrm{C}, 53.78 ; \mathrm{H}$, $5.87 ; \mathrm{N}, 9.04$.

[Pb(thiomaltolato $\left.)_{2}\right]$. Thiomaltol $(75 \mathrm{mg}, 0.53 \mathrm{mmol})$ was suspended in $2 \mathrm{~mL}$ of methanol and was dissolved by the addition of $53 \mu \mathrm{L}$ of $10 \mathrm{M} \mathrm{NaOH}$ (1 equiv) and $3 \mathrm{~mL}$ of water producing a bright orange solution. $\mathrm{Pb}(\mathrm{OAc})_{2} \cdot 3 \mathrm{H}_{2} \mathrm{O}(100 \mathrm{mg}, 0.26 \mathrm{mmol})$ was dissolved in 5 $\mathrm{mL}$ of water and was added dropwise to the reaction mixture resulting in the formation of a 
bright yellow precipitate. The reaction flask was covered in aluminum foil and sealed; the mixture was stirred for $2.5 \mathrm{~h}$ at room temperature. The solution was filtered through a fine glass frit and washed with $\sim 40 \mathrm{~mL}$ of water to obtain a bright yellow powder. Yield: $85 \%$. Mp 195 ${ }^{\circ} \mathrm{C}($ dec. $) . \quad{ }^{1} \mathrm{H}$ NMR $\left(d^{6}-\mathrm{DMSO}, 400 \mathrm{MHz}, 25{ }^{\circ} \mathrm{C}\right): \delta 2.45\left(\mathrm{~s}, 6 \mathrm{H},-\mathrm{CH}_{3}\right), 7.28(\mathrm{~d}, J=4.4 \mathrm{~Hz}$, 2H, Ar-H), $8.00(\mathrm{~d}, J=4.8 \mathrm{~Hz}, 2 \mathrm{H}, \mathrm{Ar}-\mathrm{H}) . \quad$ APCI-MS: $m / z 349.33$ [M-(thiomaltol)] ${ }^{+}$. IR (ATR): $v 724,789,805,892,1172,1210,1289,1360,1407,1448,1567 \mathrm{~cm}^{-1}$.

[Pb(3,2-HOPTO $\left.)_{2}\right]$. [ $\left.\mathrm{Pb}(3,2-\mathrm{HOPTO})_{2}\right]$ was synthesized by the same procedure used for $\left.[\mathrm{Pb} \text { (thiomaltolato })_{2}\right]$ starting from 3,2-HOPTO $(29 \mathrm{mg}, 0.20 \mathrm{mmol})$ and $\mathrm{Pb}(\mathrm{OAc})_{2} \cdot 3 \mathrm{H}_{2} \mathrm{O}(39 \mathrm{mg}$, $0.10 \mathrm{mmol})$. The product obtained was a pale yellow powder. Yield: $80 \%$. Mp 219-222 ${ }^{\circ} \mathrm{C}$ (dec.). ${ }^{1} \mathrm{H}$ NMR $\left(d^{6}-\mathrm{DMSO}, 400 \mathrm{MHz}, 25^{\circ} \mathrm{C}\right): \delta 3.91\left(\mathrm{~s}, 6 \mathrm{H},-\mathrm{CH}_{3}\right), 6.47(\mathrm{~d}, J=8.0 \mathrm{~Hz}, 2 \mathrm{H}$, Ar-H), $6.75(\mathrm{t}, J=7.0 \mathrm{~Hz}, 2 \mathrm{H}, \mathrm{Ar}-\mathrm{H}), 6.41$ (d, $J=6.0 \mathrm{~Hz}, 2 \mathrm{H}, \mathrm{Ar}-\mathrm{H})$. APCI-MS: $m / z 348.22$ [M-(3,2-HOPTO)]. HR-EIMS: $m / z 488.0096\left[\mathrm{M}^{*}\right]^{+}$(Calcd. $m / z$ 488.0101). IR (ATR): $v 708$ $756,780,798,1044,1122,1172,1228,1272,1317,1384,1412,1449,1529,1586 \mathrm{~cm}^{-1}$.

[Pb(3,4-HOPTO $\left.)_{2}\right]$. [ $\left.\mathrm{Pb}(3,4-\mathrm{HOPTO})_{2}\right]$ was synthesized by the same procedure used for $\left[\mathrm{Pb}(\text { thiomaltolato })_{2}\right]$ starting from $3,4-\mathrm{HOPTO}(60 \mathrm{mg}, 0.42 \mathrm{mmol})$ and $\mathrm{Pb}(\mathrm{OAc})_{2} \cdot 3 \mathrm{H}_{2} \mathrm{O}(80 \mathrm{mg}$, $0.21 \mathrm{mmol})$. The product obtained was a light yellow powder. Yield: $97 \%$. Mp $288-290{ }^{\circ} \mathrm{C}$ (dec). IR (ATR): $\quad v 721,744,884,944,1104,1167,1193,1312,1371,1418,1574 \mathrm{~cm}^{-1}$. Anal. Calcd. for $\mathrm{C}_{14} \mathrm{H}_{16} \mathrm{~N}_{2} \mathrm{O}_{2} \mathrm{~S}_{2} \mathrm{~Pb}$ : C, 32.61; H, 3.13; N, 5.43. Found: C, 32.47; H, 3.21; N, 5.46.

X-Ray Crystallographic Analysis. Single crystals of each compound suitable for X-ray diffraction structural determination were mounted on quartz capillaries by using Paratone oil and were cooled in a nitrogen stream on the diffractometer. Data were collected at $100 \mathrm{~K}$ on a Bruker AXS diffractometer using an area detector. Peak integrations were performed with the Siemens SAINT software package. Absorption corrections were applied using the program SADABS. Space group determinations were performed by the program XPREP. The structures 
were solved by Patterson methods and refined with the SHELXTL software package (Sheldrick, G. M. SHELXTL vers. 5.1 Software Reference Manual; Bruker AXS: Madison, WI, 1997). All hydrogen atoms were fixed at calculated positions with isotropic thermal parameters unless otherwise noted; all non-hydrogen atoms were refined anisotropically.

Structure of $\left[\mathrm{Pb}(\text { thiomaltolato })_{2}\right]$. Orange blocks of $\left.[\mathrm{Pb} \text { (thiomaltolato })_{2}\right]$ suitable for $\mathrm{X}$-ray diffraction structural determination were grown from a solution with the complex dissolved in a mixture of methanol and chloroform diffused with pentane. No solvent molecules were found in the unit cell.

Structure of $\left[\mathbf{P b}(3,4-\mathrm{HOPTO})_{2}\right]$. Orange blocks of $\left[\mathrm{Pb}(3,4-\mathrm{HOPTO})_{2}\right]$ suitable for X-ray diffraction structural determination were grown from layering a solution of the 3,4-HOPTO dissolved in acetonitrile on top of a solution of $\mathrm{Pb}(\mathrm{OAc})_{2} \cdot 3 \mathrm{H}_{2} \mathrm{O}$ dissolved in water. No solvent molecules were found in the unit cell.

Metal Competition Spectrophotometric Titrations. The $\left.[\mathrm{Pb} \text { (thiomaltolato })_{2}\right]$ solutions were prepared by first dissolving the complex in DMF and then diluting with the appropriate amount of $\mathrm{ddH}_{2} \mathrm{O}$. For each titration, $2 \mathrm{~mL}$ of $\left.\sim 50 \mu \mathrm{M}[\mathrm{Pb} \text { (thiomaltolato })_{2}\right]$ in an aqueous solution containing 1.0 M DMF was added to a quartz VWR spectrophotometer cell with a $10 \mathrm{~mm}$ pathlength sealed with a Teflon stopper. The solution was protected from light and incubated at room temperature with stirring for $5 \mathrm{~min}$ between additions of the alkaline earth metal salt solution $\left(\mathrm{CaCl}_{2}\right.$ or $\mathrm{MgCl}_{2}, 200 \mu \mathrm{M}-5 \mathrm{M}$ stock solutions in aqueous solution with 1.0 M DMF). Spectra were collected on a Hewlett-Packard 8452A (laboratory of William C. Trogler). Plotting the change in the absorbance maxima versus alkaline earth metal ion concentration (Figure S4 inset) allowed for determination of the concentration of competing metal ion that results in dissociation of the lead(II) complex. As shown in Figure $\mathrm{S} 4$ (for $\mathrm{MgCl}_{2}$ ), these titrations do not 
generate sharp isobestic points suggesting the presence of intermediate species that likely consist of 1:1 metal-ligand complexes with both lead and the group two ion.

EDTA Spectrophotometric Titrations. A $30 \mu \mathrm{M}$ solution of $\left.[\mathrm{Pb} \text { (thiomaltolato) })_{2}\right]$ was prepared in $10 \mathrm{mM}$ PIPES, $100 \mathrm{mM} \mathrm{KCl,} 1.0 \mathrm{M} \mathrm{DMF}$, pH 6.8. Stock solutions of $6.1 \mathrm{mM}$ and $0.61 \mathrm{mM} \mathrm{Na}_{2} \mathrm{EDTA} \cdot 2 \mathrm{H}_{2} \mathrm{O}$ were prepared in $10 \mathrm{mM}$ PIPES, $100 \mathrm{mM} \mathrm{KCl}, 1.0 \mathrm{M} \mathrm{DMF}$, pH 6.8 . Samples containing $2 \mathrm{~mL}$ of $\left.[\mathrm{Pb} \text { (thiomaltolato) })_{2}\right]$ were incubated with $100 \mu \mathrm{L}$ of $6.1 \mathrm{mM}$ $\mathrm{Na}_{2}$ EDTA $2 \mathrm{H}_{2} \mathrm{O}$ (10 equivalents of EDTA to $\left.\left.[\mathrm{Pb} \text { (thiomaltolato })_{2}\right]\right), 10 \mu \mathrm{L}$ of $6.1 \mathrm{mM}$ $\mathrm{Na}_{2}$ EDTA $2 \mathrm{H}_{2} \mathrm{O}$ (1 equivalent of EDTA to $\left.[\mathrm{Pb} \text { (thiomaltolato) })_{2}\right]$ ), or $100 \mu \mathrm{L}$ of $0.61 \mathrm{mM}$ $\mathrm{Na}_{2} \mathrm{EDTA} \cdot 2 \mathrm{H}_{2} \mathrm{O}\left(0.1\right.$ equivalents of EDTA to $\left.\left.[\mathrm{Pb} \text { (thiomaltolato })_{2}\right]\right)$ with agitation for $27 \mathrm{~h}$. The samples were covered in aluminum foil during incubation. 
Table $\mathrm{S} 1$. X-ray structure data for the complexes $\left.[\mathrm{Pb} \text { (thiomaltolato })_{2}\right]$ and $\left[\mathrm{Pb}(3,4-\mathrm{HOPTO})_{2}\right]$.

\begin{tabular}{|c|c|c|}
\hline & {$\left[\mathrm{Pb}(\text { thiomaltolato })_{2}\right]$} & {$\left[\mathrm{Pb}(3,4-\mathrm{HOPTO})_{2}\right]$} \\
\hline $\begin{array}{l}\text { Empirical } \\
\text { Formula }\end{array}$ & $\mathrm{PbC}_{12} \mathrm{H}_{10} \mathrm{O}_{4} \mathrm{~S}_{2}$ & $\mathrm{PbC}_{14} \mathrm{H}_{16} \mathrm{~N}_{2} \mathrm{O}_{2} \mathrm{~S}_{2}$ \\
\hline $\begin{array}{l}\text { Crystal } \\
\text { System }\end{array}$ & Monoclinic & Orthorhombic \\
\hline Space Group & $C 2 / c$ & $F d d 2$ \\
\hline $\begin{array}{l}\text { Unit Cell } \\
\text { dimensions }\end{array}$ & $\begin{array}{l}a=19.397(14) \AA \\
b=4.131(3) \AA \\
c=16.584(12) \AA \\
\beta=91.865(10)^{\mathrm{o}}\end{array}$ & $\begin{array}{l}a=8.7501(6) \AA \\
b=31.678(2) \AA \\
c=10.7750(7) \AA\end{array}$ \\
\hline Volume, $Z$ & $1328.2(16) \AA^{3}, 4$ & $2986.7(4) \AA^{3}, 4$ \\
\hline Crystal size & $0.42 \times 0.27 \times 0.12 \mathrm{~mm}^{3}$ & $0.20 \times 0.18 \times 0.10 \mathrm{~mm}^{3}$ \\
\hline $\begin{array}{l}\text { Temperature } \\
(\mathrm{K})\end{array}$ & $100(2)$ & $100(2)$ \\
\hline $\begin{array}{l}\text { Reflections } \\
\text { collected }\end{array}$ & 4922 & 6335 \\
\hline $\begin{array}{l}\text { Independent } \\
\text { reflections }\end{array}$ & $1509[R($ int $)=0.0426]$ & $1694[R(\mathrm{int})=0.0447]$ \\
\hline $\begin{array}{l}\text { Data/restraints } \\
\text { /parameters }\end{array}$ & $1509 / 0 / 88$ & $1694 / 0 / 98$ \\
\hline $\begin{array}{l}\text { Goodness-of- } \\
\text { fit on } F^{2}\end{array}$ & 1.100 & 1.097 \\
\hline $\begin{array}{ll}\text { Final } & R \\
\text { indices } & \\
\mathrm{I}>2 \sigma(\mathrm{I})^{a} & \end{array}$ & $\begin{array}{l}R 1=0.0338 \\
w R 2=0.0827\end{array}$ & $\begin{array}{l}R 1=0.0261 \\
w R 2=0.0673\end{array}$ \\
\hline $\begin{array}{l}R \text { indices (all } \\
\text { data) }^{a}\end{array}$ & $\begin{array}{l}R 1=0.0345 \\
w R 2=0.0833\end{array}$ & $\begin{array}{l}R 1=0.0271 \\
w R 2=0.0680\end{array}$ \\
\hline
\end{tabular}



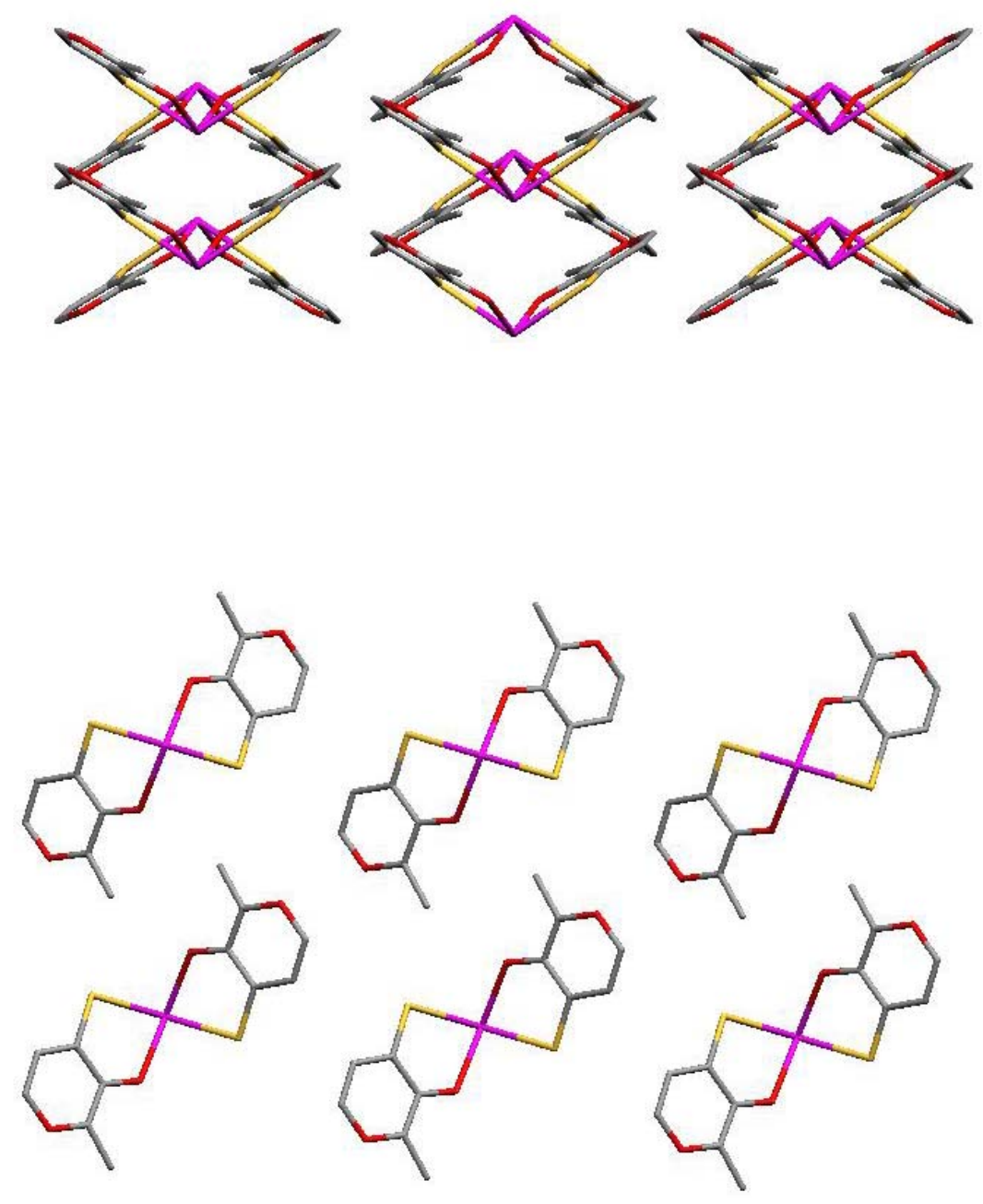

Figure S1. Packing diagram of $\left.[\mathrm{Pb} \text { (thiomaltolato) })_{2}\right]$ along the crystallographic $b$ axis (top) and $c$ axis (bottom). The 'nested' arrangement of the complexes along the $b$ axis results in an intermolecular close contact. 


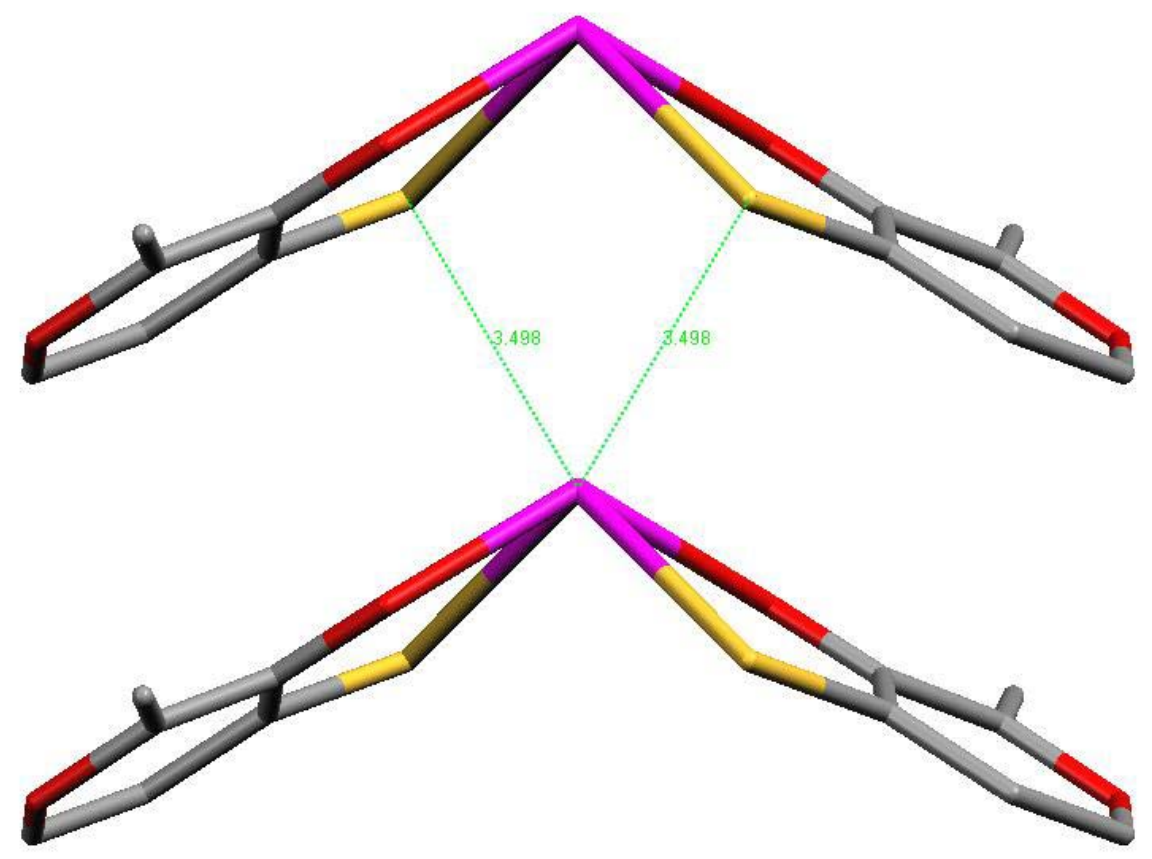

Figure S2. The 'nested' arrangement of $\left.[\mathrm{Pb} \text { (thiomaltolato })_{2}\right]$ along the crystallographic $b$ axis results in an intermolecular close contact between the lead(II) ion and the sulfur atoms of a neighboring complex at $\sim 3.50 \AA$ (shown as green dotted line). 

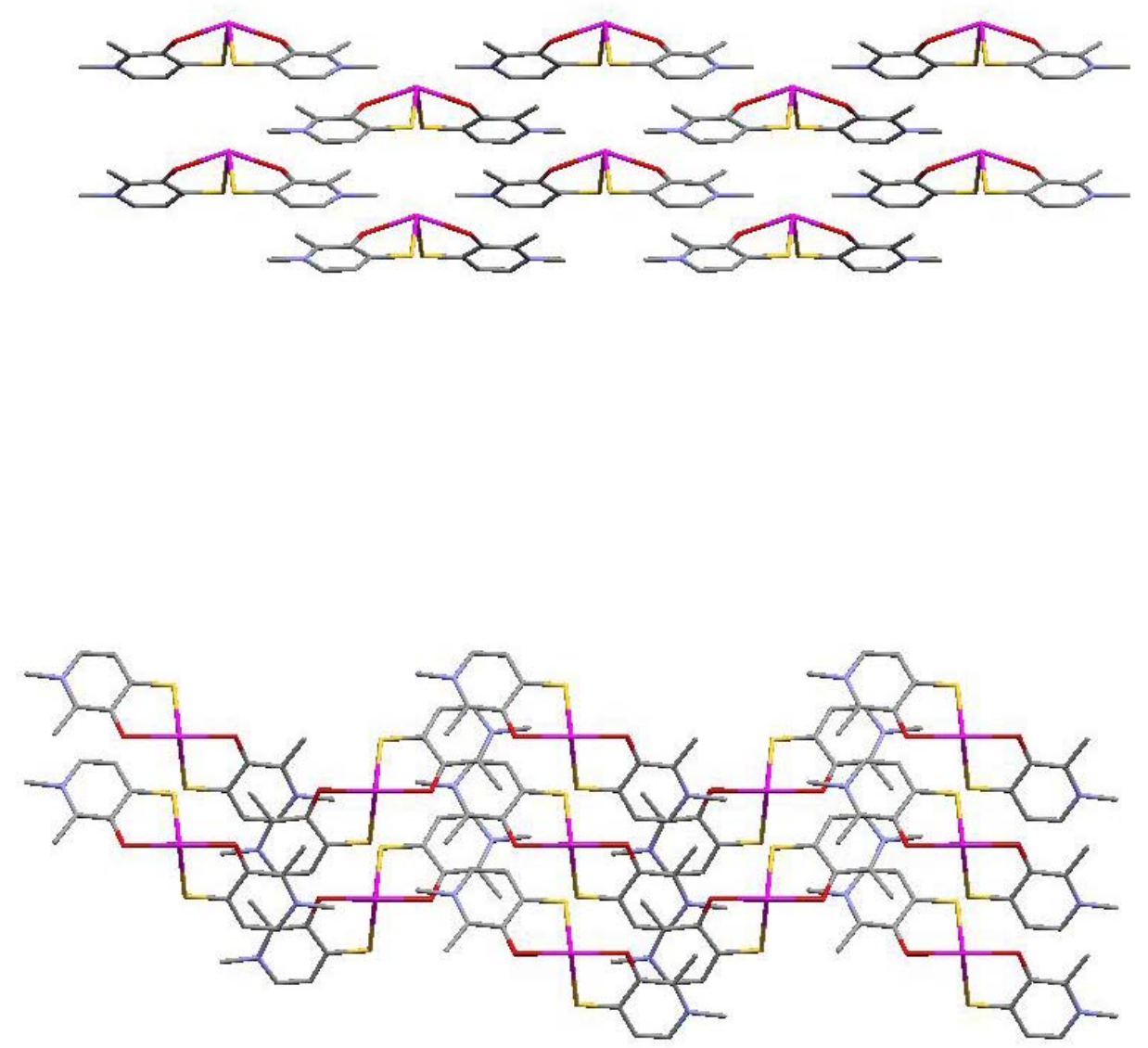

Figure S3. Packing diagram of $\left[\mathrm{Pb}(3,4-\mathrm{HOPTO})_{2}\right]$ along the crystallographic $a$ axis (top) and $c$ axis (bottom). No significant intermolecular close contacts are observed. 


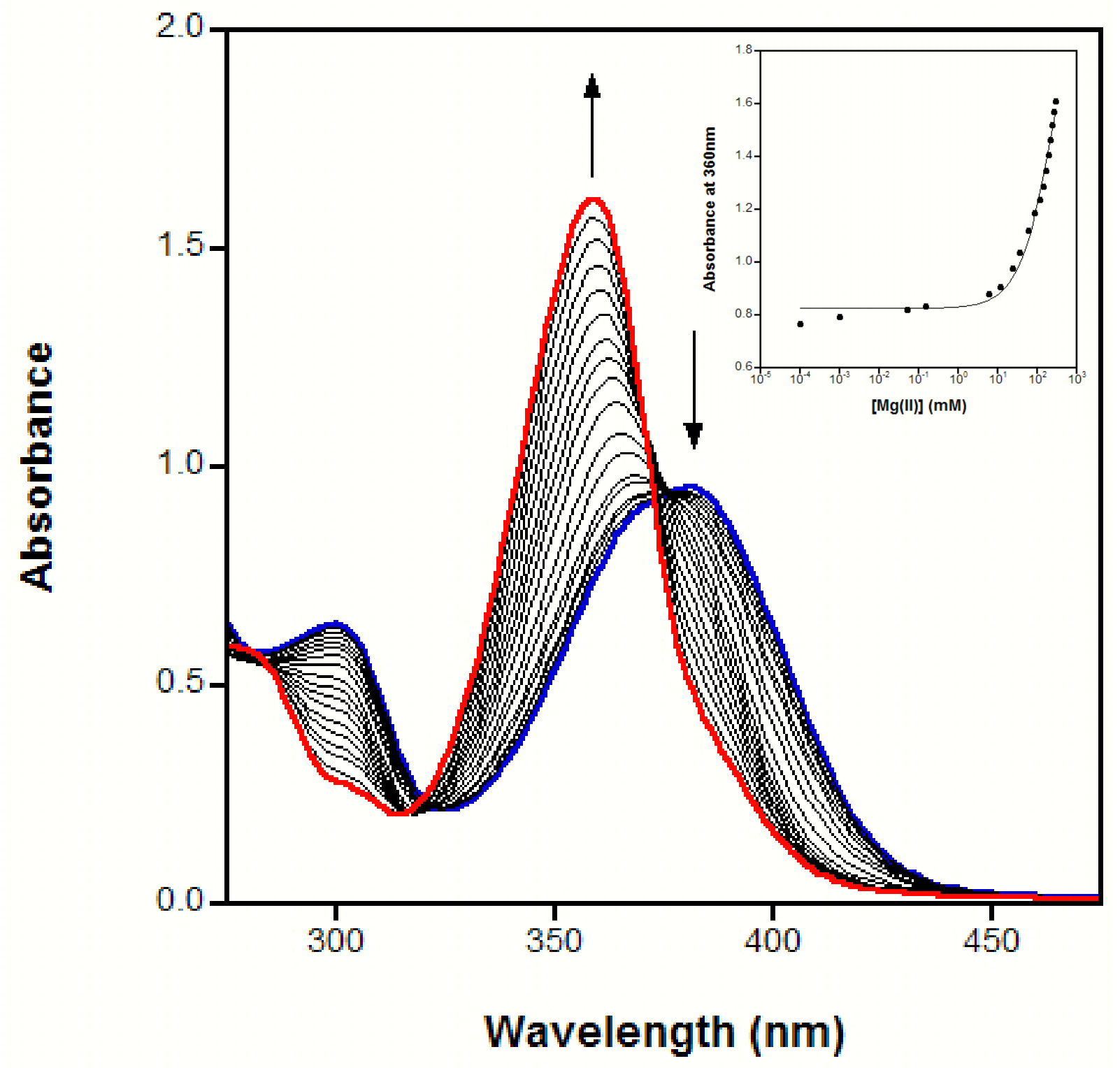

Figure S4. Electronic spectra of $\left.[\mathrm{Pb} \text { (thiomaltolato })_{2}\right]$ titrated with increasing amounts of $\mathrm{MgCl}_{2}$ in aqueous solution containing 1.0 M DMF. The solid blue line is the initial $\left.[\mathrm{Pb} \text { (thiomaltolato })_{2}\right]$ spectrum $(\sim 50 \mu \mathrm{M})$; arrows indicate changes upon addition of $\mathrm{MgCl}_{2}$; the final spectrum is shown in the solid red line. Inset shows the absorbance at $360 \mathrm{~nm}$ versus increasing concentration of $\mathrm{MgCl}_{2}$. 


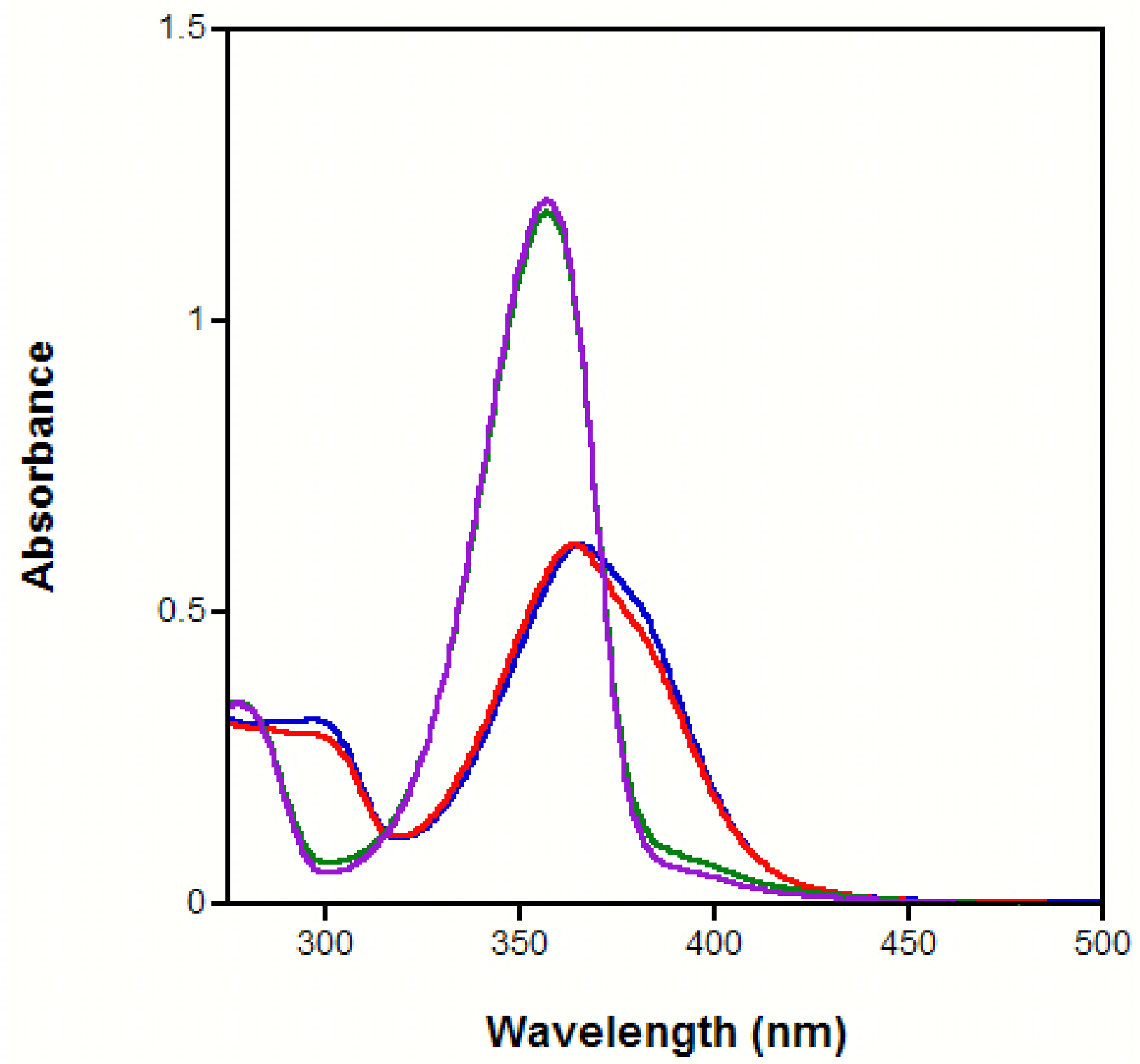

Figure S5. Electronic spectra of $\left.[\mathrm{Pb} \text { (thiomaltolato })_{2}\right]$ before and after incubation with $\mathrm{Na}_{2} \mathrm{EDTA} \cdot 2 \mathrm{H}_{2} \mathrm{O}$ in $10 \mathrm{mM}$ PIPES, $100 \mathrm{mM} \mathrm{KCl}, 1.0 \mathrm{M} \mathrm{DMF}, \mathrm{pH}$ 6.8. The solid blue line is the initial $\left.[\mathrm{Pb} \text { (thiomaltolato })_{2}\right]$ spectrum $(30 \mu \mathrm{M})$, and then after $\sim 24 \mathrm{~h}$ incubation with 0.1 equiv of EDTA (red), 1.0 equiv of EDTA (green), and 10.0 equiv of EDTA (purple). 